\title{
On the dynamies of farm size distribution in Finland
}

\author{
DeVendra SAHaL
}

\begin{abstract}
This study attempts to explain why farm structure in Finland is what it is. The static aspects of size distribution are summarised by means of log-normal distribution and tested with respect to data on more than 500 communes for years 1959 and 1969. As to the dynamic aspects, despite some correlation between percentage growth and size at the beginning of the time period and which is believed to be partly spurious, the observed phenomena do not seem to be incompatible with the proposed version of law of proportionate effect. The latter need not be observed at every point in time.
\end{abstract}

\section{Introduction}

Studies of farm size distribution seem to be few presumably because it does not make sense to study "business concentration" in an industry characterized by many entrepreneurs operating under a relatively competitive market structure. However, it is unlikely that farm entrepreneurs fail to account the (expected) scales of utilization in decisions related to investment in capital inputs and classifying the latter into durable and indivisible categories does not enhance our understanding of the former. Of course, cost curves yield no prediction about the distribution of firm size. In any event, a basic understanding of the process of farm growth is necessary if we do not want to formulate production functions on a purely ad hoc basis.

This is a sufficient justification of the present study which attempts to explain why the farm structure in Finland is what it is but even more important, why it changes the way it does. The theoretical framework of the study presents no difficulty because "much of the discussion pertaining to the size of the firm is equally applicable to the size of the plant" (SHEN 1965, p. 420), especially in agriculture. In fact, by concentrating on farm size rather than the firm size we are able to bypass most of the taxonomic difficulties associated with the question as to what is a firm. Our sample is, in fact, more closely related to technology since the basic unit is the plant rather than the firm (SHEN 1965, p. 422). 


\section{The model}

Underlying the basic model is the view that entrepreneurs' decisions concerning scale of utilization are governed by the desire to realize the economics of scale subject to organizational constraint. Imperfections in capital market are ignored. Variations in elasticity of demand with regard to farm size are assumed, not too unreasonably, to be nonexistent and it is tested ${ }^{1}$ whether "there is a limit to the rate at which any firm can grow, a limit provided by the capacity of its existing management ... Economics of growth exist for all sizes of firm ... but they disappear once an expansion based on them has been completed" (PENROSE 1968, p. 262-263).2,3

Granted that the Penrose effect is a force to be reckoned with, it would tend to nullify the desire to improve the economics of scale so that we are likely to observe over a 'sufficiently' long period of time that the probability of a given proportionate change in size during this time interval is the same for all farms regardless of their size at the beginning of the period. Thus a simple explanation of the process of firm growth is provided by the law of proportionate effect. ${ }^{4,5}$

In the present context, if such a law indeed holds, the farm size distribution is likely to be log-normal since the law states that ${ }^{6,7}$

1 We shall presently see that the test is only indirect which is because of the empirical necessity, of course, a direct test seems to be all but impossible anyhow. As Mrs Penrose herself puts it: The patterns sketched need fit no individual firm; firms of the same size will not necessarily grow at the same rate, and the point at which the rate of growth starts its real decline will be different for different firms. Furthermore, this point may be extremely hard to locate statistically, for in practice growth takes place in spurts, and periods of relative decline may well be followed by periods of accelerated growth (PENROsE 1968, p. 213).

2 Elsewhere Mrs Penrose is even more explicit: "Since the services from 'inherited' managerial resources control the amount of new managerial resources that can be absorbed, they create a fundamental and inescapable limit to the amount of expansion a firm can undertake at any time ... There are thus two aspects of the nature of the managerial limit on the rate of expansion of a firm: First, the services available from the existing managerial group limit the amount of expansion that can be planned at any time because all plans for expansion absorb some of the services available from this group and the larger and more complex the plans the more services will be required to digest and approve them on behalf of the firm.... Secondly the amount of activity that can be planned at a given time limits the amount of new personnel that can profitably be absorbed in the 'next period' (PENrose 1968, p. 48-49).

3 Williamson $(1966$, p. 1) readily agrees: "One of the most discredited concepts in the theory of the firm is that of an 'optimum size' firm .... there is no more reason to expect profitability to decline with size than there is evidence to suggest that it does. This raises the question as to what does limit the size of a firm. The answer . . . is that there are important costs entailed in expanding the size of a firm, and that these expansion costs tend to increase with firm's growth rate." JoRGENSON (1967), LucAs (1967) and TrEADwAY (1970) also assume that there are rising internal adjustment costs in the expansion of firms.

4 With the previously noted qualification concerning the length of the time period.

5 Reader familiar with the paper of SHEN (1965) will recognize its influence here and subsequently.

6 A variate subject to a process of change is said to obey the law of proportionate effect if change in the variate at any stage in the process is a random proportion of the previous value of the variate (Arrchison and Brown 1957, p. 22).

7 Indeed, a number of studies attempt to fit skewed distributions to microeconomic data (HART and Prais 1956, Simon and Bonini 1958), but the underlying theory has not been made clear. 


$$
r_{j}=\frac{x_{j}-x_{j}-1}{x_{j}-1} \quad j=1, \ldots, n
$$

where $\left\{r_{j}\right\}$ is a set of mutually independent random variables, independent of the set $\left\{x_{j}\right\}$.

By successive substitution

$$
\begin{aligned}
x_{j} & =\left(r_{j}+1\right) x_{j}-1 \\
& =\left(r_{j}+1\right)\left(r_{j}-1+1\right) x_{j}-2 \\
& \cdots \cdots \cdots \cdots \cdots \cdots \cdots \cdots \cdots \cdots \cdots \cdots \\
& =\left(r_{j}+1\right)\left(r_{j}-1+1\right) \ldots\left(r_{1}+1\right) x_{o}
\end{aligned}
$$

Therefore, when $\left|r_{j}\right|$ is small compared to 1 and $n$ is large, a random variable is lognormally distributed so that

$$
\mathrm{F}(\mathrm{x})=\int_{0}^{x} \frac{e^{-1 / 2} \frac{[(\log \varepsilon-\mu) / \sigma]^{2}}{\sigma}}{\varepsilon \sigma \sqrt{2 \pi}} \mathrm{d} \varepsilon
$$

A priori it seems necessary to add some further qualifications to this simple model. Thus exit occurs most frequently for farms of small size ${ }^{8}$ so the probability that a farm will die is unlikely to be independent of its size. Consequently we suppose that the law is valid for the size distribution of all the farms excepting those that leave the industry. With this qualification in mind, the dynamic aspects of the model are easily represented by ${ }^{9}$

$$
\mathrm{V}\left(\mathrm{x}_{\mathrm{t}}+1\right)=\beta^{2} \mathrm{~V}\left(\mathrm{x}_{\mathrm{t}}\right)+\sigma_{\mathrm{t}}^{2}
$$

where $\mathrm{V}\left(\mathrm{x}_{\mathrm{t}+1}\right)$ and $\mathrm{V}\left(\mathrm{x}_{\mathrm{t}}\right)$ are the variance of the logarithms of the farm size at time $\mathrm{t}+1$ and time $\mathrm{t}$; the test for the model is whether $\beta^{2}$ is unity because if small farms grow more rapidly than big, it will be less than unity, there will be regression towards the mean, and vice versa. The residual variance $\sigma_{t}^{2}$, of course, simply measures the deviation in growth about the average rate of growth.

Of course, it may turn out that the model is applicable only to the farms exceeding a certain minimum efficient size. But that remains to be seen.

\section{Results}

Log-normal distribution was fitted to the average size data at the regional level of aggregation. Given the scarcity of the degrees of freedom available, farm size data were combined with the forest size data. The goodness of fit of the theoretical distribution was tested using a $\mathrm{x}^{2}$ test with $n$-3 degrees of freedom where $\mathrm{n}$ is the number of groups. The results are presented in Table 1. While the normal distribution is decisively rejected, the fit of log-normal is

8 especially in view of the governmental intervention in Finnish agriculture.

9 See Hart and Prais (1956, p. 172) for the algebra involved. Equation (4) represents the law of proportionate effect in its strong form. 
Table 1. Farm size and forest size distribution in Finland at regional level of aggregation(a

\begin{tabular}{cccc}
\hline census & year & $\begin{array}{c}\mathrm{P}>\mathrm{x}^{2} \text { under the theoretical assumption of } \\
\text { log-normal distribution } \\
\text { normal distribution }\end{array}$ \\
\hline 1. & 1959 & 0.02 & $<10^{-3}$ \\
2. & 1969 & 0.16 & $<10^{-3}$ \\
\hline
\end{tabular}

(a) only two census data are available. Given the reorganized regions in 1969 the number of observations were further reduced for this year.

not particularly impressive $\mathrm{e}^{\mathbf{1 0}}$ either, except when a graphical comparison (not presented here) is made between the two.

The possible existence of a theoretical bias in these results depends on whether the cost functions and conditions of entry and exit are different between farms and associated $^{11}$ forests. One may draw one's own conclusion. ${ }^{12}$ To us, however, the static aspects of the size distribution are of decidedly secondary interest.

Turning, therefore, to the dynamic aspects ${ }^{13}$ first we present some evidence as to the Penrose effect. The latter implies that due to rising internal adjustment costs, over a sufficiently long period of time, the rapidly growing farms in the beginning of this period become relatively slowly growing farms, at the end of this period. Consequently, one way of testing the hypothesis of growth reversal would be to see if correlation between growth rate and the base year (1959) farm size is any different from the correlation between growth rate and the end of year (1969) farm size.

The mean, M (and standard deviations) for various farm size classes were first computed. Growth, in turn, ${ }^{14}$ was defined as $M_{t+j}-M_{t}$ and $\frac{M_{t+j}-M_{t}}{M_{t}}$ $(\mathrm{x} 100)$ and correlation $(\mathrm{r})$ as well as regression $(\beta)$ coefficients between

10 Indeed, Srmon and Bonini (1958) argue that the log-normal curve is a special case of the yule distribution. For the problem at hand it is, however, difficult to see how the latter (which implies an assumed birth process in addition to the law of proportionate effect) could be superior to the former given that there is nothing like an ease of entry in agriculture.

11 Because of the nature of data employed.

12 Where it was possible to group I did fit the distributions to individual data as well but found it difficult to draw any definite conclusions on the basis of such limited observations. These results (not presented here in order to save space) would be, however, supplied to interested readers.

13 At the commune level of aggregation. We shall presently see that the results, as theoretically anticipated, are considerably improved at the disaggregated level. Dictated by the empirical necessity (otherwise, we would like to test the hypothesis at the farm level itself) the data utilized in obtaining the following results consist of observations on 488 communes in 1959 and 548 communes in 1969. Due to computational reasons beyond the author's control, for 1969 data farms in the size classes $1-4.99$ ha, in $25-29.99$ ha and in $50-74.99$ (but only for north Finland) were omitted. However, it appears that omission is, by and large, inconsequential to the results presented here.

14 If correlations are calculated between ratios containing a common variable the presence of observation errors may lead to spurious inferences about the correlations obtaining in the population (Briggs 1962). For this reason we do not quite believe that results in Table 2 are sufficient to reject the law of proportionate effect. Moreover, given the log-normal hypothesis we should, instead, test correlation between $\log \left(\mathrm{M}_{\mathrm{t}}+\mathrm{j} / \mathrm{M}_{\mathrm{t}}\right)$ and $\log \left(\mathrm{M}_{\mathrm{t}}\right)$ but once again spurious correlation problem exists. 


\begin{tabular}{ccccccc}
\hline & & $\mathrm{M}_{\mathrm{t}}$ & & & $\mathrm{M}_{\mathrm{t}}+\mathrm{j}$ & \\
& $\mathrm{r}$ & $\beta$ & $\mathrm{s}$ & $\mathrm{r}$ & $\beta$ & $\mathrm{s}$ \\
\hline $\mathrm{M}_{\mathrm{t}+\mathrm{j}-\mathrm{M}_{\mathrm{t}}}$ & -0.75 & -0.23 & 12.68 & -0.07 & -0.03 & 19.25 \\
& & $(4.43)$ & & & $(0.26)$ & \\
$\frac{\mathrm{M}_{\mathrm{t}+\mathrm{j}}-\mathrm{M}_{\mathrm{t}}}{\mathrm{M}_{\mathrm{t}}}$ & -0.74 & -0.099 & 5.59 & -0.05 & -8.011 & 8.31 \\
\hline
\end{tabular}

Results of $\mathrm{t}$-test are indicated in parentheses.

growth rate and $\mathrm{M}_{\mathrm{t}}$ as well as between growth rate and $\mathrm{M}_{\mathrm{t}+\mathrm{j}}$ were computed. The results along with the standard error of estimate (s) are presented in Table 2.

These empirical results are consistent with theoretical expectation. Thus the correlation coefficient between growth rate and the base year farm size is -0.75 but only -0.07 between the former and the end of year farm size! Admittedly, the two coefficients have the same sign. However, given the drastic change in the size of the two coefficients, we are in no position to reject the Penrose effect i.e., the hypothesis of growth reversal.

Our hypothesis is that the farms in each size class should have the same average chance of increasing or decreasing in proportion to their present size. However, it may be that this law of proportionate effect holds only for farms exceeding the "minimum efficient sizen in the industry. Thus, it will be desirable to see what evidence we can bring to bear on the problem of where the average cost curve does turn up. If there is a sharp increase in the unit costs below certain critical farm size, the number of farms below that size should be less than the number predicted by the theoretical model. This was studied by fitting Pareto distribution to the data. However, no systematic sharp bend could be detected even upon dividing and separately studying the data on a geographical basis. ${ }^{15}$

It would seem that no qualification (of the minimum efficient size) to the law of proportionate effect is required; an impression which is strengthened upon studying the more advanced dynamics of the farm size distribution. This is done by running a regression of the variance of the logarithms of the farm size in the bivariate distribution (theoretical formulation (4). The results are presented in Table 3 .

15 This seems to be an expected result (cf footnote 10). 


\begin{tabular}{|c|c|c|c|c|}
\hline & $\beta^{2}$ & $\mathrm{~S}\left(\beta^{2}\right)$ & $\mathrm{r}$ & $\sigma_{\mathrm{t}}^{2}$ \\
\hline 1. For the whole country. & 0.74 & 0.21 & 0.7 & 0.015 \\
\hline 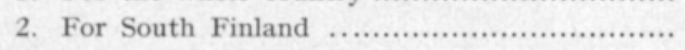 & 1.02 & 0.04 & 0.99 & $9.01 \times 10^{-5}$ \\
\hline 3. For North and Middle Finland ..................... & 0.61 & 0.35 & 0.6 & 0.04 \\
\hline
\end{tabular}

At conventional 5 percent risk level estimates of $\beta^{2}$ are not significantly different from unity. Consequently small and large farms are seen to have the same average proportionate growth. In short, the crucial element of the theoretical model is not rejected by the data.

The growth variance $\sigma_{\mathrm{t}}{ }^{2}$ is far below unity which implies that the variation in size mobility of farms (or the extent to which farms move from one sizeclass to another) or intensity of competition over time has been (though larger in north and middle Finland than in south Finland) microscopically small. That, however, is not surprising.

\section{Discussion}

Summing up it can be stated that the observed phenomena do not seem to be incompatible with the particular interpretation of the law of proportionate effect advanced here. In particular, within the scope of the data available to us, we find that the Penrose effect is not rejected. Thus there is a limit to the growth. ${ }^{16}$ In addition, however, we find that economics of growth seem to exist for all sizes of farm ${ }^{17}$ (though not after the expansion has been completed). Indeed, evidence concerning a "minimum efficient size" was lacking and more important, $\beta^{2}$ was found not to be not significantly different from unity. Even more improved results are expected at the farm level.

Supposing that the Penrose effect is, somehow, ignored (and consequently the correlation between growth rate and size also). In that case the alternative explanation must be accepted that the growth of farms is determined by a multiplicative ${ }^{18}$ interplay of stochastic forces practically beyond anyone's control, for a few strategic factors would not suffice; a long list of causes must be supplied. This explanation allows one to assume that farm size is exogenously determined in the theoretical model of agricultural economy. However, it also implies that a governmental intervention of unprecedented magnitude would be a minimum prerequisite to any contemplated alteration in farm size distribution in Finland.

16 One may, instead, emphasize, say, the locational aspects but that is tantamount to assuming, inter alia, that these aspects matter only after the expansion and not during it. Of course, the impact of managerial ability on the growth of farm firms has been emphasized by many authors (11).

17 At least from and beyond 5 ha size.

18 Not additive as the normal distribution implies. In addition, we find that the justification, of fitting Yule distribution to the data at hand, is hard to come by. 


\section{REFERENCES}

Artchison, J. \& Brown, J. A. C. 1957. The lognormal distribution. Cambridge University Press, London.

ANon 1962. Agriculture Vol. II. Census of agriculture, data per commune 1959. Official Statistics of Finland. III: 54. Helsi nki.

- 1970: Agriculture Vol. II. Census of agriculture, data per commune 1969. Official Statistics of Finland. III: 67. Helsinki.

Briggs, F. A. 1962. The influence on the correlation of ratio. Econometrica 30, 1: 162-177.

Hart, P. E. \& Prais, S. J. 1956. The analysis of business concentration. J. Royal Statist. Soc. 2: $150-191$.

JoRgenson, D. W. 1967. The theory of investment behaviour, in sDeterminants of Investmant Behaviour,, edited by R. Ferber. Nat. Bur. Econ. Res. New York.

Lucas, R. E. 1967. Adjustment costs and the theory of supply. J. Political Economy 75,4: $321-334$.

PAtric, G. F. \& Eisgruber, L. M. 1968. The impact of managerial ability and capital structure on the growth of the farm firm. Amer. J. Agric. Economics 50:491-506.

Penrose, E. T. 1968. The theory of the growth of the firm. Basil Blackwell. Oxford.

SHEN, T. Y. 1965. Economics of scale, expansion path, and growth of plants. Rev. Econ. Statist. 47: 420-428.

Srmon, H. A. \& Bonini, C. P. 1958. The size distribution of business firms. Amer. Econ. Rev. 1958: 607-617.

Treadway, A. 1970. Adjustment costs and variable inputs in the theory of the competitive firm. J. Econ. Theory 2,4: 329-347.

Williamson, J. 1966. Profit, growth and sales maximization. Economica 33, February: 1-16. 


\title{
SELOSTUS
}

\section{Suomen maatilojen kokojakauman dynaamisista ominaisuuksista}

\author{
Devendra Sahal
}

Tämä tutkimus pyrkii selvittämäăn Suomen maatilarakenteen muodostumiseen vaikuttavia tekijōitä. Kokojakautuman staattisia ominaisuuksia on approksimoitu log-normaalijakautuman avulla ja testattu yli 500 kunnan lukuarvoilla vuosilta 1959 ja 1969 . Jonkin verran korrelaatiota esiintyy maatilakoon ja sen prosentuaalisen kasvun välillä. Tämän korrelaation päätellään olevan osittain keinotekoista, niinpä maatilakoon kasvun dynaamisia ominaisuuksia voidaan tulkita suhteellisen muutoksen lain (Arтchrson ja Brown 1957) avulla. Tällöin ei tarvitse olettaa lain pätevän jokaisena ajanhetkenä. 